Journal of Economics and Policy
http://journal.unnes.ac.id/nju/index.php/jejak

\title{
The Impact of Social Safety Net Programs on Poor Household Income
}

\author{
Hengky S.H. Prayitno ${ }^{凶},{ }^{2}$ Dwi Budi Santoso, ${ }^{3}$ Marlina Ekawaty \\ 1,2,3Faculty of Economy, University of Brawijaya, Malang \\ Permalink/DOI: https://doi.org/10.15294/jejak.v11i2.16049
}

Received: January 2018; Accepted: May 2018; Published: September 2018

\begin{abstract}
Indonesian government has established social safety net programs to reduce poverty and increase the productivity and income of poor households. Among other provinces in Indonesia, East Java has the highest poverty rate. Thus, this research aims to analyze the effectiveness of social safety net programs in reducing poverty rate in East Java. This research uses quantitative approach to measure the contribution of social safety net programs towards the income of poor households in East Java. This research employs equivalent simultaneous equation with three-stage least square (3SLS) method on secondary cross section data obtained from National Socio-Economic Survey (Susenas), March 2015. This research calculates and analyzes the impacts of social aid, social protection and labor market intervention programs towards the income of poor household income. The results show that social aid and labor market intervention programs have positive implication on the income of poor households. On the other hand, social security has no significant implication. Moreover, social security provides a safety net when a household faces unexpected situation such as redundancy, accident and death. Social security programs prevent poor households for being poorer.
\end{abstract}

Key words : social safety net, poor household, income

How to Cite: Prayitno, H., Santoso, D., \& Ekawaty, M. (2018). The Impact of Social Safety Net Programs on Poor Household Income. JEJAK: Jurnal Ekonomi dan Kebijakan, 11(2), 244-262 doi:https://doi.org/10.15294/jejak.v11i2.16049

\footnotetext{
Corresponding author:

Address: Veteran Street, Malang, Indonesia

E-mail: hengky.sh.prayitno@gmail.com
} 


\section{INTRODUCTION}

One of government efforts to reduce poverty is by establishing social safety net programs. Social safety net programs take forms of government, private sector and community initiatives to transfer income or consumption towards poor households, protect vulnerable households from risks, and increase the social status of marginalized households (Suharto, 2009). Social safety net programs aim to reduce poverty and vulnerability by stimulating efficient labor markets, lessening exposure to risks of vulnerable citizens, and improving their capacity to protect themselves against threats and interruption/loss of income (Asean Development Bank, 2003).

In ASEAN, social safety net programs have been established in several countries such as in Vietnam, Thailand, Malaysia and Indonesia (Asean Development Bank, 2016). As can be seen in Figure 1, in Vietnam, the social safety net programs successfully reduced proportion of population below the poverty line from $13.4 \%$ in 2009 to $7 \%$ in 2015. Similarly, in Malaysia the proportion of poor population dropped from $3.8 \%$ to $0.6 \%$ in those 6 years range. The proportion of poor population in Indonesia, on the other hand, was only slightly reduced from $13.3 \%$ in 2009 to $10.9 \%$ in 2015. Additionally, the figure also shows that in 2015 the proportion of Indonesian poor population was the highest among those four countries.

Indonesia's population living below the poverty line in 2015 was 27.72 million (BPS, 2015). Three regions having the largest population are East Java, Central Java and West java with $4.775,4.5$ and 4.48 million poor people respectively. Those data sum that East Java was the region which had the highest population below poverty in Indonesia. Moreover, as can be seen in Figure 2, East Java's poor population declined relatively slower than the national figure from 2010 to 2015.

Figure 2 presents the amount of incentive for every poor citizen. Government budgets for social protection from year to year tend to increase. According to the data taken from Cabinet Secretariat (2016), the budget for social protection rose significantly in 2016, almost 7 times than that of 2015 .

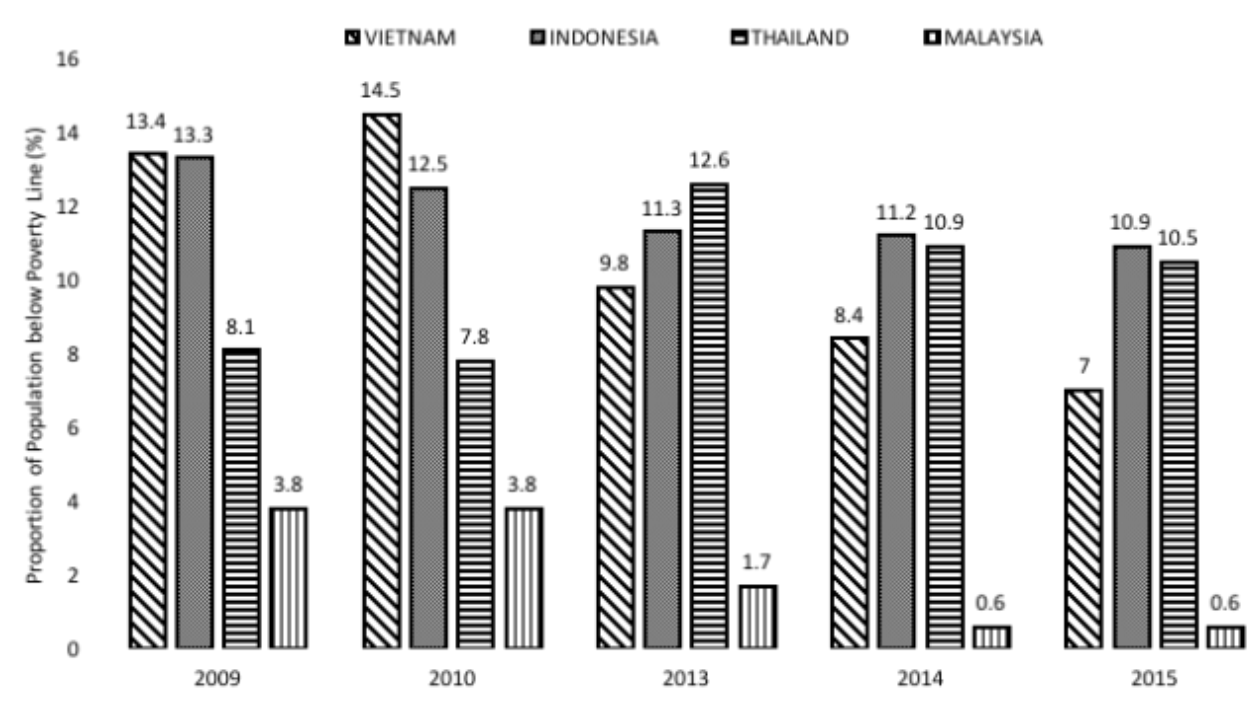

Figure 1. Proportion of Population below Poverty Line in ASEAN Countries Source: (Asean Development Bank, 2016) 


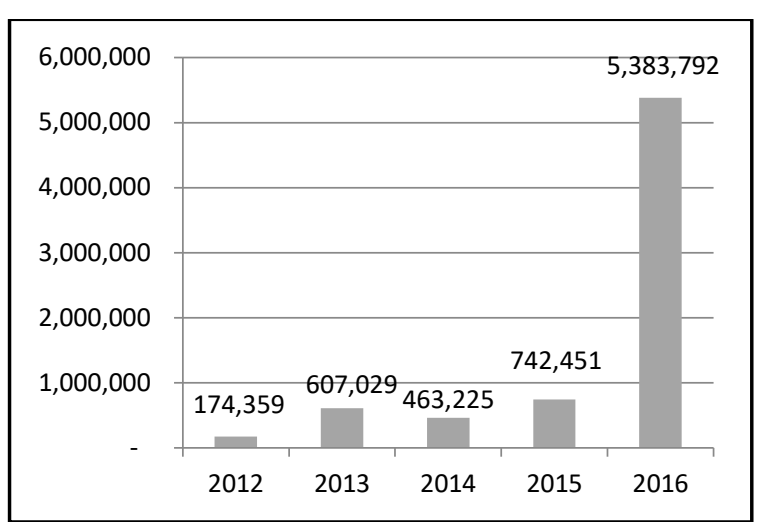

Figure 2. The Amount of Incentive for Every Poor Citizen.

Source: Cabinet Secretariat

The increase in social protection budget which has a large proportion in 2016 aimed to improve the welfare of the poor. This increase should also be followed by a significant decrease in the percentage of poor people. However, based on data taken from the Central Bureau of Statistics (2016), it can be seen that the decline of the poor was not directly proportional to the budget that had been issued by Indonesian government.

Figure 3 shows the statistics of the number of poor Indonesians experiencing a considerable decrease in the period of 2013, which decreased from 29.25 million to 28.17 million people. If seen from the government spending for social protection in 2013, there was a five-fold budget increase compared with 2012 from IDR 174 thousands per person to IDR 607 thousands per person, but in 2016 the increase of social protection budget was considerably high, seven-fold increase compared with 2015, not showing a sharp reduction in the number of poor people.

Figure 4 shows that social safety net program budget increases by years. In East Java, the budget has been raised more than four times from IDR 730 million in 2010 to IDR 2,915 million in 2015. Therefore, it is very important to evaluate the impact of social safety net programs which has been established within those years to find out the effectiveness of the programs in reducing poverty. In this research, we focus on analysing the program establishment in East Java. This analysis is very strategic since East Java is the main contributor to national poor population.

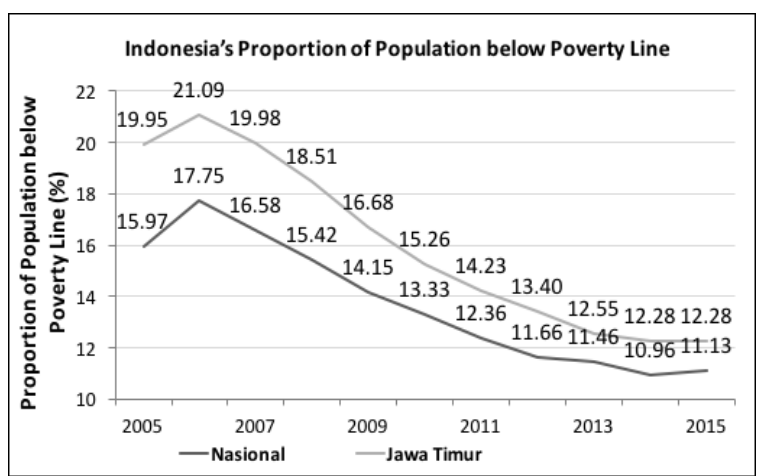

Figure 3. Poverty Proportion vs. Social Safety Net Budget

Source: Indonesia Central Bureau of Statistic (BPS), compiled series.

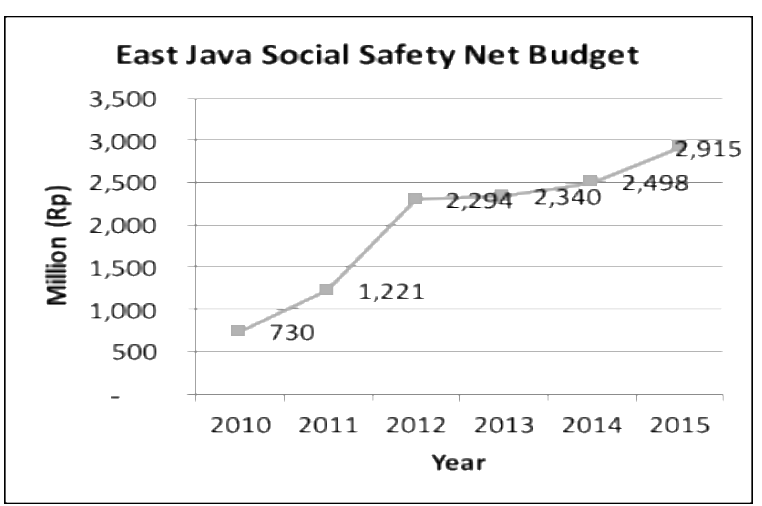

Figure 4. Social Safety Net Budget for East Java Source: Indonesia Central Bureau of Statistic (BPS)

In theory, social safety net programs should be able to break the vicious cycle of poverty, proposed by Nurske in (Jhingan, 2014). Social safety net in Indonesia has been established after the economy crisis in 1998. The economy crisis raised the awareness of the importance of social safety net for country stability. Social safety net is a comprehensive program to tackle poverty and also aims to diminish vulnerability, 
incompetence, physical weakness and isolation. Social safety net programs attempt to improve the citizen wellbeing, based on economic approach which is measured by household income. An increase in household income helps poor household getting out of poverty.

Based on the previously presented facts, the effectiveness of social protection program to reduce poverty level has becomes the main focus of this research. Therefore, we define some hypothesis based on the underlying data whether Social Aid and Security affect the basic capacity of poor household in East Java. Furthermore, the investigation is required to understand the correlation between basic Labor Market Intervention (LMI) and business capacity of poor households in East Java. Finally, the effect of three aspects of Social Aid, Social Security and LMI to the income of poor household is need to be explored.

Social safety net attempts to raise household income through two approaches, by increasing human capital which includes human resource education and heath level and increasing physical capital which includes programs giving liquid investment. As can be seen in Figure 5, human capital increases physical capital leading to productive capacity increase which then increases income. This process is repeated recursively. Therefore, this study focuses on analyzing social safety net programs which have impacts on human capital and subsequently physical capital. The impacts on human capital and physical capital improvement towards income are also analyzed.

The social safety net programs in Indonesia can be grouped into three different categories, namely social aid, social security and labour market intervention.
These programs are provided in both in-kind transfer and cash grand forms. The social aid (SA) program category covers both in-kind transfer through Subsidised Rice Delivery (Raskin) and cash grand through Cash Transfer for Poor Students (Bantuan Siswa Miskin). However, this study only focuses on Raskin. The labor market intervention (LMI) program category is provided as a cash grand through Credit for Business Program (Kredit Usaha Rakyat/KUR), Group of Joint Venture (Kredit Usaha Bersama/KUB/KUBE), National Program for Community Empowerment (Program Nasional Pemberdayaan Masyarakat/PNPM) or Co-operation (Koperasi) activities. Social security program offers in-kind transfers activities such as Health Insurance Program (Jamkesmas). Jamkesmas provides health insurance.

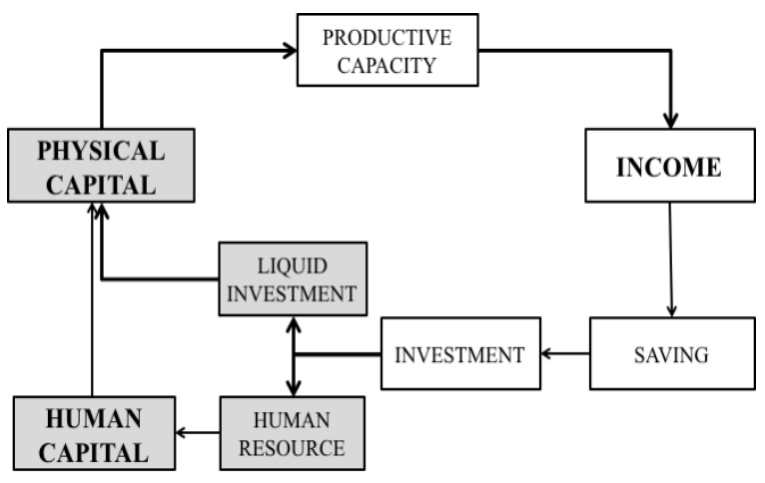

Figure 5. The Cycle of Poverty

Source: Modified from Ragnar Nurske 1953

These social safety programs can be mapped based on its potential impacts on human and physical capital as shown in Figure 6. Social aid and social security programs affect human capital by giving access to poor households on better education and health services and providing food as one of basic needs. Labor market intervention and human capital affects physical capital that may improve the income of poor households. 


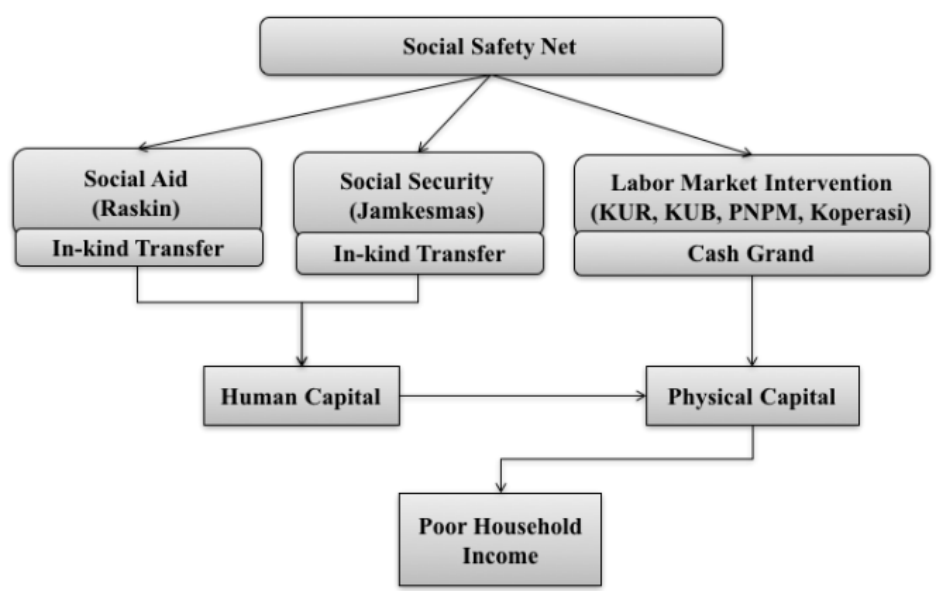

Figure 6. Indonesia Social Safety Net Programs improving the Income of Poor Households

Based on the background of the problems, the actual condition, the theoretical framework and the thinking framework, this study proposes hypotheses as follows Social Aid positively affects basic capacity of poor households in East Java, Social Security positively affects basic capacity of poor households in East Java, Labor Market Intervention positively affects business capacity of poor households in East Java, Basic capacity of poor households in East java positively affects business capacity of poor capacity in East Java, Business capacity of poor households in East Java positively affects the income of poor households in East Java.

This study evaluates and analyzes the impacts of each program category of social safety net towards the income of poor household as mapped in Figure 5. This study uses quantitative approach described in the previous chapter presenting Research Method. Afterwards, this research discusses the results in Results and Discussion and completes this study with summary and suggestion in Conclusion.

\section{RESEARCH METHODS}

This study employs secondary cross section data collected from National SocioEconomy Survey (Susenas) in March 2015 to investigate the impacts of social safety net programs to poverty reduction. The survey has been conducted by Indonesia Central Bureau of Statistic (BPS) each year started from 1992 to collect data related to human resource quality, especially for aspects of social economy. Susenas 2015 had two main instruments: Susenas core (VSEN15.K) and Susenas consumption model (VSEB15.KP). Susenas core includes social demography variables such as the number of people within household, education, health, fertility, family planning, housing and social security. Susenas consumption model includes household expenditure for primary, secondary and tertiary needs and sources of income.

The number of samples collected by Susenas during March 2015 in East Java was 29,601 households resided in East Java Province with 2,996 survey blocks. The sampling method used in this survey was Proportional to Size (PPS) - Linear Systematic sampling. This study focuses on poor households, whose expenditure was below the poverty line. These households had expenditure per capita accounted by IDR 305,171 per month. The number of poor household samples which fall into this category was 3,641 households. This study uses STATA 12 software to analyze the data. 
There are two variables employed in this study, endogenous and exogenous variables. Endogenous variables include Human Capital $(\mathrm{H})$ measured by access to education and health services. Physical Capital (F) measured by liquid assets and non-liquid assets owned by the surveyed households. Income $(\mathrm{Y})$ measured by expenditure per capita.

Each value of endogenous variable depends on the value of exogenous variables. The exogenous variables of each endogenous variable are Human Capital $(\mathrm{H})$ include Social Aid (SA), measured by the amount of rupiahs received in Subsidised Rice Delivery (Raskin) by poor households. Social Security (SS) measured by the number of social security cards held by households, including pension/veteran, superannua-tion, accident and death insurance, lay off insurance, and Family Health Card (Kartu Keluarga Sejahtera) or Social Protection Card (Kartu Perlindungan Sosial), a special insurance card issued by government for poor households.

Physical Capital (F) include Labor Market Intervention (LMI) measured by sums of credit received by poor households for one year duration including Credit for Business Program (Kredit Usaha Rakyat/ KUR), National Program for Community Empowerment (Program Nasional Pemberdayaan Masyarakat/PNPM), bank credits,
Group of Joint Venture (Kredit Usaha Bersama/KUB/KUBE), Co-operation and other credits.

Income (Y) include Physical Capital (F), in addition to those variables, this research employs some variables of exogenous control. These variables consist of the number of people within a household $(\mathrm{N})$, the head of family's educational level (Educ), and the head of family's age (Age). These variables show the characteristic of a household. In summary, the variables are presented in Table 1.

Widarjono (2013) stated that in many cases, the economy variables do not only have one-sided relationships or causality relationships. Instead, those variables may also have two-sided relationships which can be modeled using simultaneous equation having equal number of equations and endogen variables. The main characteristic of simultaneous equation is that an endogenous variable of an equation can be an exogenous variable in other equations (Gujarati \& Porter, 2012). As listed above, this study involves three endogenous variables and five exogenous variables. As shown in Figure 3, human capital, an endogenous variable, becomes an exogenous variable of physical capital. Physical capital which is also an endogenous variable becoming an exogenous variable of income.

Table 1. Measurement Variables

\begin{tabular}{llll}
\hline Variable & \multicolumn{1}{c}{ Description } & \multicolumn{1}{c}{ Scale } & \multicolumn{1}{c}{ Category } \\
\hline $\mathrm{Y}$ & Per capita Income & Ratio & Endogenous \\
$\mathrm{H}$ & Human Capital & Ordinal & Endogenous \\
$\mathrm{F}$ & Physical Capital & Ordinal & Endogenous \\
$\mathrm{SA}$ & Social Aid & Ratio & Exogenous \\
$\mathrm{SS}$ & Social Security & Ordinal & Exogenous \\
$\mathrm{LMI}$ & Labor Market Intervention & Ordinal & Exogenous \\
$\mathrm{N}$ & Number of People in a Household & Ratio & Exogenous \\
Educ & The Education Level of the Head of Family & Ordinal & Exogenous \\
Age & The Age of the Head of Family & Ratio & Exogenous \\
\hline
\end{tabular}


According to Widarjono (2013), a simultaneous equation can be estimated if the sum of the coefficients of structural equation equals to the coefficients in the reduced form. Simultaneous equations can also be solved using identification method. Identification method consists of two methods: order condition and rank condition. In identification using order condition, there are several notations that must be completed first. ' $A$ ' is the number of endogenous variables in the simultaneous model, ' $a$ ' is the number of endogenous variables in specific equations. ' $\mathrm{B}$ ' is the number of exogenous variables in the simultaneous model, ' $b$ ' is the number of exogenous variables in the specific equations.

There are two rules in this method that has to be followed. The first rule: the equation is identified if presenting at least A1 variable (either endogenous or exogenous) in the model. If identified as A-1, then the model is identified. If more than $A-1$, the model is over-identified. The second rule: An equation is identified if $B-b \geq a-1$;

If $\mathrm{B}-\mathrm{b}<\mathrm{a}-\mathrm{1}$, the equation is not identified;

If $B-b=a-1$, the equation is identified. If $\mathrm{B}-\mathrm{b}>\mathrm{a}-1$, the equation is over-identified.

The identification of order condition becomes the necessary condition. In order to meet sufficient condition, rank condition is used. The rank from the matrix refers to square sub matrix. The biggest order will be identified from determinant not being equal to zero. Based on order identification and rank condition, an equation, in a simultaneous equation system, will be identified or not based on the following principles, if $\mathrm{B}$ $-\mathrm{b}>\mathrm{a}-1$ and the rank matrix $\mathrm{X}$ is known more than $A-1$, the equation is over identified; if $\mathrm{B}-\mathrm{b}=\mathrm{a}-1$ the rank matrix $\mathrm{X}$ equals to $A-1$, the equation is exactly identified; if $\mathrm{B}-\mathrm{b} \geq \mathrm{a}-\mathbf{1}$ and the rank matrix $X$ is less than $A-1$, the equation is not identified; if $B-b<a-1$ and the matrix $X$ is less than $A-1$, the structural equation is not identified.

According to Gujarati \& Porter (2012), the method used for simultaneous equation is Indirect Least Square (ILS) or Two-Stage Least Square (2SLS). ILS method is properly used for exact identification. In this method, ILS is used for reduced form used to predict the original coefficient from its reduced form coefficient. TLS method is specifically used for over-identified model. Using linier combination from specified variables, the stochastic endogenous variables can be altered to form instrumental variable method. On this estimation, the specified variables will act as instruments or proxies for endogenous variables.

The formulation of simultaneous equation model is afterwards tested its identification for order condition and rank condition. The results of identification are presented in Table 2. The function of equation model is determined as identified if it is identified or just/exact identified.

Table 2. The Identification on Each Equation in Simultaneous Method

\begin{tabular}{lcccccc}
\hline \multicolumn{1}{c}{ Equation } & K & K & M & m & K-k ....m-1 & Info \\
\hline Income & 6 & $\mathbf{2}$ & 3 & 3 & $4>\mathbf{2}$ & Over-identified \\
Basic Capacity & 6 & 4 & 3 & $\mathbf{1}$ & $\mathbf{2}>\mathbf{0}$ & Over-identified \\
Business Capacity & 6 & 3 & 3 & $\mathbf{1}$ & $3>0$ & Over-identified \\
\hline
\end{tabular}


The following rules are used to identify simultaneous equation system (Falah, Mustafid, and Sudarno, 2016), if B-b < a-1, it is under-identified. The parameter estimation cannot be conducted. Developing different model can be its solution. If $\mathrm{B}-\mathrm{b}=$ $\mathrm{a}-1$, it is just identified. The parameter estimation technique used is Indirect Least Square (ILS) method. If $\mathrm{B}-\mathrm{b}>\mathrm{a}-\mathbf{1}$, it is overidentified. The parameter estimation technique used is Two-Stage Least Square (2SLS) in which: $\mathrm{a}=$ the number of endogenous variables in the equation; $b=$ the number of exogenous variables in the equation; $\mathrm{B}=$ the number of exogenous variables in the system.

When compared to 2SLS simultaneous equations model being Limited Information, the 3 SLS method is more Full Information where simultaneous equation model uses all available information. Moreover, 3SLS method provides consistent estimation and asymptotically more efficient (Hausman, 1974).

Therefore, this research firstly defines a function which measures the impact of social aid and social security to human capital as shown in equation (1). In this equation, this research uses the number of people within a household and the head of family's educational level control variables.

$$
H=f(S A, S S, N, E d u c)
$$

Afterward, this research defines a function which measures the impacts of labor market intervention and human capital to physical capital as shown in equation (2). As in equation (1), this research also uses the number of household member and the head of family's educational level as control variables.

$$
F=f(L M I, H, N, E d u c)
$$

Lastly, this research defines a function which measures the impact of physical capital to income as shown in equation (3). The control variables in this function are the education level and the age of the head of family.

$$
Y=f(F, E d u c, A g e)
$$

The linear regression of functions shown in equations (1), (2) and (3) are represented in equations (4), (5) and (6) respectively.

$$
\begin{aligned}
H= & \alpha_{0}+\alpha_{1} S A+\alpha_{2} S S+\alpha_{3} N+ \\
& \alpha_{4} E d u c+\varepsilon_{H} \\
F= & \beta_{0}+\beta_{1} L M I+\beta_{2} H+\beta_{3} N+ \\
& \beta_{4} E d u c+\varepsilon_{F} \\
H= & \gamma_{0}+\gamma_{1} F+\gamma_{2} E d u c+\gamma_{3} \text { Age }+ \\
& \varepsilon_{Y}
\end{aligned}
$$

$\alpha_{0}, \beta_{0}$, and $\gamma_{o}$ are constants. $\alpha_{i}, \beta_{i}$, and $\gamma_{i}$ (i> o) are variable coefficients, and $\varepsilon_{H}, \varepsilon_{F}$, and $\varepsilon_{Y}$ are the error terms/disturbances of the equations.

The value of constants and coefficients from simultaneous equation can be calculated through ${ }_{3} \mathrm{SLS}$ method since the degree of freedom is above 1,000 .

\section{RESULTS AND DISCUSSION}

From the demographic aspect, the number of East Java population is the second largest after West Java. Based on 2006 BPS data as the result of projected 2010 Population Census, the population was $39,075,152$. The average population growth rate in East Java in the last 6 years has been below $1 \%$ which is about $0.67 \%$ annually. When viewed based on the composition of sex, female population has bigger ratio than that of male population. It is reflected in the value of sex ratio accounted by $97.48 \%$. Every 100 of females, there are approximately 97 
males. When viewed from the poverty level, eastern Java has a relatively larger poverty population compared with other provinces in Indonesia. However, the percentage of poverty rate in East Java, both in its districts and municipalities, shows the decreasing trend of the poverty level even though the poverty rate fluctuates from year to year. The poverty in East Java province in the last 7 years continued to decline, but in the year 2016, the rate was $12.05 \%$. In general, the number of poor people in East Java was approximately 4.7 million people, based on 2016 survey.

In addition, the Gini Ratio commonly used to measure inequality or inequality of income distribution in an area tends to increase in the last 7 years. This condition reflects the widening gap between the rich and the poor in East Java.

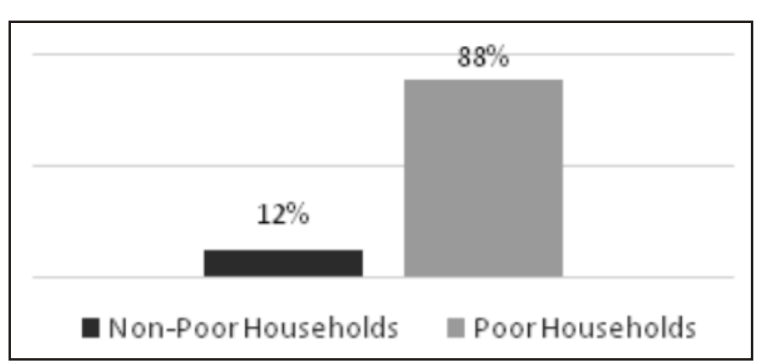

Figure 7. The Percentage of Poor Households in East Java

Source : Susenas 2015, March Period

Based on the results of East Java's SocioEconomic Survey for the period of March 2015 illustrated in the pie chart of Figure 7 , from 29,601 surveyed households, 12 percent of which was poor households. The poor households had per capita income of less than IDR. 305,171,00. Of this number not all poor households get a KKS card as an indicator of membership of the Social Protection program. The number of households holding a KPS is 44 percent of all poor households (Figure 8).

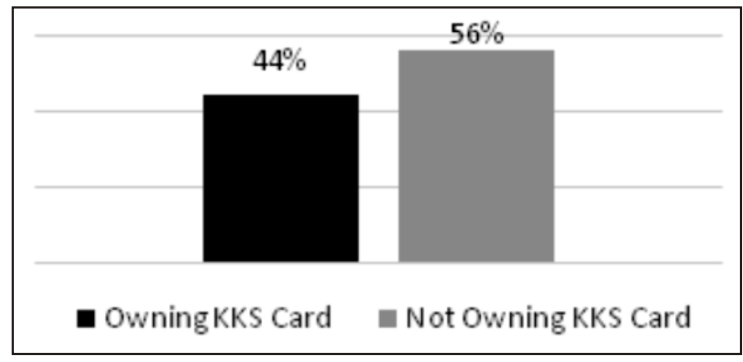

Figure 8. The Ownership Percentages of KKS Card Holders

Source: Susenas 2015, March Period

Amartya Sen in Todaro dan Smith (2011) suggested that the problem of poverty is not just a matter of income, but it is related to the capabilities that must be possessed by an individual, some of which are related to access, such as education, health and employment, to establish a quality, affordable, and fair education for all Indonesians.



Figure 9. The Percentages of the Head of Poor Households' Educational Level. Source: Susenas 2015, March Period

In order to achieve this goal, the Education Budget in East Java becomes top priority in the budgeting system of East Java. The education budget in East Java accounted by IDR 5.6 trillions (including transfer funds) of total expenditure of IDR 23 trillion (Ministry of Education and Culture, 2016). The government is aware of the educational condition of the poor households, 47 percent of poor households not graduating from primary school or equivalent levels. The majority of the head of poor families are school drop outs and not graduating from primary school level (Figure 9). 
Jhingan (2014) argued that to change the economic backwardness and generate the ability and motivation to move forward, it is important to improve people's knowledge and skills. Figure 10 presents the proportions of the head of poor families' age, being mostly productive age (from $15-64$ years old) while the remaining 27 percent is nonproductive.

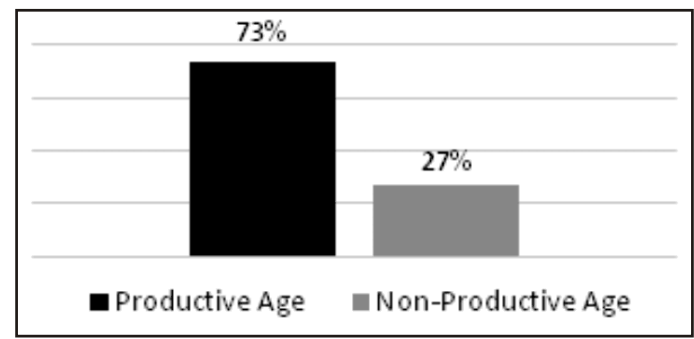

Figure 10. The Productive Age Ratio of the Head of Poor Households

Source: Susenas 2015, March Period

The improvement of basic human capacity strongly supports the acceleration of growth and expansion of a region's economic development. Higher basic human capacity in a region will lead to higher productivity of the workforce and higher chances of generating innovation as the key factors of sustainable growth.
The estimation results calculated using 3SLS method of each equation are provided in Table 3. Table 3 shows estimated coefficient values of equation (4), social aid, social security and education have positive correlations to human capital. Meanwhile, the number of household members has negative correlation. Both social aid and the head of households' educational level influence human capital with $1 \%$ significance. Social aid programs increase the household's access to basic education and health services which then improve human capital of the households. This finding is in line with Sumarto, Suryahadi, \& Widyanti (2004) research stating that in-kind transfer of social aid fulfills a household's basic needs and increases quality of life. The variable coefficient of the head of household's educational level implies that each increment of education level raises household human capital to 6.179 scale. This finding supports the statement that social aid, which provides better access to basic education services, improves household human capital.

Table 3. Coefficient Estimation

\begin{tabular}{|c|c|c|c|}
\hline Equation & Variable & $\begin{array}{c}\text { Constant/Coefficient } \\
\text { Value }\end{array}$ & Prob > IZI \\
\hline \multirow{5}{*}{$\begin{array}{l}\text { H: Human Capital } \\
\text { (equation (4)) }\end{array}$} & Constant & -159.2318000 & 0.000 \\
\hline & SA & 0.0000197 & 0.000 \\
\hline & SS & 5.8901560 & 0.472 \\
\hline & $\mathrm{N}$ & -0.4782523 & 0.126 \\
\hline & Educ & 6.1799070 & 0.000 \\
\hline \multirow{5}{*}{$\begin{array}{l}\text { F: Physical Capital } \\
\text { (equation (5)) }\end{array}$} & Constant & 2.5701850 & 0.000 \\
\hline & LMI & 0.2255552 & 0.000 \\
\hline & $\mathrm{H}$ & 0.0073511 & 0.000 \\
\hline & $\mathrm{N}$ & 0.0071850 & 0.066 \\
\hline & Educ & 0.0067170 & 0.241 \\
\hline \multirow{4}{*}{$\begin{array}{l}\text { Y: Income } \\
\text { (equation (6)) }\end{array}$} & Constant & 234544.8000000 & 0.000 \\
\hline & $\mathrm{F}$ & 14730.0300000 & 0.025 \\
\hline & Educ & 485.1073000 & 0.135 \\
\hline & Age & -8.5193590 & 0.910 \\
\hline
\end{tabular}


On the other hand, even though social security has a positive impact towards human capital, the impact is insignificant. Kertonegoro (1982) stated that social security gives protection to source of income loss caused by redundancy or additional costs of living. Thus, as stated in Chen, Palmer, \& Si (2016), households which are protected by social security programs have small chance for being poorer. Social security provides a safety net for households when there are unexpected conditions happened such as accident, death and redundancy. Thus, even though social aid does not significantly increase household income, social aid becomes very important to cut down the number of poor population and save poor households to be chronic poor households.

Estimated coefficient values of equation (5) shows that all exogenous variables have positive correlation towards physical capital. Labor market intervention and human capital impact physical capital with $1 \%$ significance. Labor market intervention programs such as Group of Joint Venture (Kelompok Usaha Bersama/KUBE) and National Program for Community Empowerment (Program Nasional Pemberdayaan Masyarakat/PNPM) provide poor households with liquid capital and assist their business to increase their physical capital. Liquid capital given by the government provides the ability to establish a business to increase income. This finding is in line with the research done by Priadana (2010) which stated that business initiative which is promoted through KUBE has provided new job opportunities and also created new entrepreneurs. Wenagama (2017) research, which uses simultaneous equation to analyze PNPM program establishment in Kediri, Tabanan, Bali, also shows that credits given through PNPM has partially raise household income. Table 2 also shows that labor market intervention has higher coefficient than human capital in equation (5). It implies that labor market intervention, which is given as cash grand, has more impact than other inkind transfer programs of social safety net.

The coefficient values of equation (6) show that physical capital has positive impact on household income with $5 \%$ significance. The head of household's educational level also has positive impact on income, but it is insignificant. The head of household's age has a negative impact on income. However, since the table also shows that the head of household has insignificant impact on income, we can safely put this variable aside in this discussion.

According to the results of data processing, the relationship between social protection with the income of poor households can be submitted as follows the role of social aid to income, according to its nature, Social Aid is a short term subsidy for poor households capable of affecting basic capacity. Social aid program should be a program capable of meeting basic human needs (Suharto 2009). In its implementation, Social Aid is mostly in the form of goods transfer, such as scholarship for poor students and Rice Aid program (Raskin), as a dominant type of social aid implemented since 2003 aimed at reducing the burden of expenditure of Target Households through the provision of rice. Hence, it is useful in improving food security of the Target Households and increasing access to food both physically and economically (affordable price to Target Households). The operational aid for poor students is directly proportional to the value of direct aid for poor students in the form of student allowance. The provision of social aid for education is provided 
through two methods, namely through educational institutions and school allowance funds. So far this practice has affected access to education and health services. According to Djojohadikusumo (1994), education is important in improving human dignity. Through the ability to manage the nature information. The ability to improve human dignity at micro level is measured from the ratio of household members who can read Latin alphabets and the ratio of healthy household members.

Poor households in East Java has good ratio of literacy and health level, indicating that government services in the education and health sectors are able to positively influence the improvement of basic capacity of poor households. The role of Social Security to income. The Social Security in Indonesia is in the stage of revolution. Started in 2014, all government-managed guarantee models were made into one administrator, the National Health Care Security (Badan Pengelola Jaminan Sosial/ $B P J S)$. Poor households, registered under the Public Health Insurance (Jamkesmas) program, will automatically receive Health Insurance from BPJS with insurance premium paid by the government. As for other social security programs, the majority of poor households is not covered because most of them are working in the informal sectors. According to the data, the majority of the head of poor households has primary school education backgrounds and drops out from primary school. Therefore, they face difficulties to access basic services. The educational factor of the head of household becomes a reflection of the use of basic access to health facilities. The ratio of sick household members to the utilization of public health center facilities based on 2015 Susenas data was 37.05 percent.
The level of awareness of the utilization of basic services, especially the use of health facilities resulting in social security having insignificant effect on access to basic services. This is due to very low utilization of basic services (especially health access). This opinion is supported by the study (Sparrow et al. 2013) which stated that poor people's health insurance programs have less impact on the poor because of the lack of accurate data for poor households. Tobing dan Jonyanis (2014) argued that administrative requirements are an obstacle in access to health care. Thus, it can be said that government spending on health insurance premiums has not been perceived as significant benefits by society. They do not realize that they are in the category of vulnerable to poverty because they are in poverty.

Labor Market Intervention for poor households is implemented in the National Program for Community Empowerment, Credit for Business Program, Group of Joint Venture and Co-operatives. The ratio of participation of poor households in the labor market intervention is illustrated in Figure 5.8. The number of poor households which obtain a labor market intervention program of 9.5 percent can be considered very little. Based on data results, the role of labor market interventions for poor households has significant effect in increasing the income of poor households. These results are in accordance to the research conducted by Maskie \& Alfitri (2014), Priadana (2010), and Director of Co-operation and UMKM State Ministry of Development Planning (2014) stated that increasing the capacity of assets through additional business capital can increase income due to increased business capacity leading to productivity increase. 
Increased productivity has implications for income increase.

Social protection, as an effort to improve the living standards of poor households, is a government program, theoretically and practically becoming an effort to break the poverty cycle. Social protection should focus on improving human resource capacity, strengthened through educational variables in intervening equations as well as structural equations. Education simultaneously affects access to basic services, asset capacity and income. The government ability to improve the capacity of human resources, especially human resources below the poverty line can be implemented by increasing the coverage of social protection participants. Social protection programs, correctly delivered, are the key to reduce poverty.

The implementation of social protection program can be said as effective when social assistance variables and labor market intervention have a positive and significant relationship in the increase of business capacity. It can be seen from the equation of Basic Capacity and Business Capacity which has a positive and significant relation to income. However, the social security variable in this study has a positive and insignificant relationship.

Empirically Labor Market Interventions have a positive and significant relationship to business capacity because Labor Market Interventions are implemented through the provision of venture capital for poor households with either micro schemes or low interest banking access, being forms of social protection directly provided to the target groups. According to its characteristics, labor market interventions are given to productive poor households, poor households having businesses or jobs.
With the coefficient value of 0.225 , it indicates that every increase of one scale in Labor Market Interventions influences $\mathbf{0 . 2 2 5}$ to business capacity increase. It can be interpreted that Labor Market Intervention implemented in the form of Business Credit, PNPM and Co-operation still needs to be improved. According to Putra's (2015) research, it is still necessary to have effective distribution, monitoring and evaluation mechanism in order to run better. According to Wenagama (2017), a participative role of citizens is needed in order to establish sustainable program. Thus, based on arguments from previous researchers, small coefficient value of labor market interventions is due to inappropriate distribution mechanisms, poorly implemented programs and poor participatory roles of poor households.

Social protection programs in the form of social aid have a positive and significant relation to Basic Capacity. Social aid aiming to provide access to basic education and health has a coefficient value of 0.00097 , indicating that the implementation of social aid is still very low. Based on the findings of the National Team of Accelerated Poverty Reduction ( $\mathrm{TNP}_{2} \mathrm{~K}, 2 \mathrm{2015}$ ), it is still necessary to refine the targeting, disintegrated database of program beneficiaries and program using annual non-sustainable targeting method. According to Tobing and Jonyanis (2014), the distribution pattern and administrative requirements become a constraint to the distribution of Social Aid. According to Mardiana (2012), the bureaucratic administration is not understood by poor households, so they may face difficulties to complete administrative requirement. Thus, it can be said that the social assistance program is currently constrained by the pattern of distribution and system of 
responsibility for the implementation of social assistance programs.

In its implementation according to Supeno's study (2011), the target beneficiaries of Raskin program have income ranging from IDR 90 to 120 thousands, 85 percent of under privileged families. 99 percent of respondents stated that Raskin is used for daily consumption. However, according to Ratna Sari (2017), the distribution of poor needs data renewal of the target recipients. Interpretation differences in the categorization of poor households among government agencies are suspected as a weakness in the definition of poor households. The Ministry of Social Affairs, the Ministry of Empowerment and the Central Bureau of Statistics define poor households in accordance with their respective perceptions, as evidenced by some literatures presenting different definitions to poverty.

Social Security is a research variable which has a positive but not significant influence. Social security is a safety program which supports poor households for being poorer Kertonegoro (1982). In accordance with the data collected by Susenas, the implementation of Public Health Insurance in East Java shows the membership rate of less than 50 percent. Meanwhile, social security is able to provide its holders a sense of security while working. Moreover, according to (Khafidoh 2015), social security ownership provides a sense of comfort to their owners in carrying out the work. However, according to Tobing \& Jonyanis (2014), not all poor households have social security cards because many poor people do not have identity cards as an administrative requirement. Hence, to improve its application, the distribution method and administration services of social security need to be evaluated.

Of the three social protection programs, empirically social aid has a positive and significant impact on basic capacity. Basic capacity and labor market interventions have a positive and significant impact on business capacity. The business capacity has a positive and significant impact on the income of poor households. Labor market intervention is the most positive and significant program for increasing the income of the poor households through the increase of business capacity, so it can be said that all social protection programs have a role in capital growth as a key to poverty reduction. This finding is in accordance with the opinion of Nurske in Jhingan (2014). The establishment of human capital and venture capital for poor households through social protection programs is essential to poverty reduction. All social protection programs, namely social aid, social security and labor market interventions, have a positive effect. Although the effect of social security is insignificant, it does not mean that poor households do not need social security. The empirical result of this research shows that the influence of business capacity on poor household income is relatively small, by 14,700 . This coefficient has a range of 5 percent when compared with the poverty line value of 305,000 . It means that an increase in one unit of business capacity can only increase 14,700 , so that the current social protection program is still effective to increase the income of poor households slightly below the poverty line. Based on the coefficient value, current social protection program can be improved according to the findings of previous research. 
Based on the distribution procedures of social protection programs, the distribution of the Labor Market Intervention program taking form of cash grant has the greatest impact on poor household income compared to social aid provided in the form of goods. Even social security provided through third parties or other institutions has no effect on basic capacity leading to insignificant or no effect on the income of poor households.

In accordance with the production theory, Labor Market Intervention program is one form of capital strengthening with a target group of poor households of productive age and has a willingness to do business. Labor market Intervention has an effect on employment creation and the growth of new entrepreneurs. Labor market intervention, based on per capita income growth theory, is a key element of capital formation. Labor Market Intervention is a form of physical addition of assets directly affecting the capitalization of capital.

Social aid, with a goal to improve human resource capacity through subsidizing primary needs, especially food and education, has a very small level of influence. It is because the subsidy has not been able to meet the standards of decent living. Based on research conducted by Supeno (2011), social recipients have income ranging from IDR 90 to 120 thousands, 85 percent of under privileged families, 99 percent of them consuming Raskin daily. It shows that social aid, although relatively small but still very necessary, is particularly needed for poor households in the chronically poor category.

\section{Research Implication}

Based on the research results, some of variables it can be highlighted that Social aid has a significant effect on basic capacity, in other words, social aid which is government intervention in improving the quality of human resources through the fulfillment of basic needs has been in accordance with the theory of poverty reduction, but albeit at a low level. Social aid remains implemented because social aid has a role in improving human resources through education and health. According to Hyman (2010), social aid is a short-term solution for long-term investment as it directly provides access to education and health services increasing the basic capacity of human resources. Therefore, in order to increase the impact of social aid, it is necessary to evaluate the implementation of the program further in terms of both target and distribution pattern.

Another highlight is that Labor market intervention program has an effect on improving business capacity leading to increasing the income of poor households. Labor market intervention is the most influential social protection programs of the social aid program. The labor market intervention program provided in the form of micro-capital is a labor intensive program. Therefore, this program is able to have a direct impact on business capacity having positive implications to increasing income of poor households. In line with previous research as expressed by oleh Maskie \& Alfitri (2014), Priadana (2010) and Wenagama (2017), in order to increase the income of poor households, policies should be developed supporting the opening of business opportunities for poor households.

In the case of social security, this study shows that this variable does not have any impact, in accordance with its nature to provide security for poor households not to fall into more severe poverty (Suharto 2006). The government has issued a budget to pay social insurance premiums, but it has not 
been maximally utilized by poor households due to no existing accident.

Each social protection program has its own characteristics for poverty reduction. Social protection in the form of beneficial social aid improves the welfare of poor households that are far below the poverty line or chronically poor category according to Haughton \& Khandker (2009). While the labor market intervention program affects poor households in the category of persistently poor. Social security benefits all categories of poor households because social security becomes a safeguard program to keep poor households from being poorer. Thus, the gain of social protection program needs to be improved.

\section{Research Constraint}

This study merely describes the business capacity, social security ownership and labor market intervention quantitatively. Therefore, the value measurement of business capacity, social security ownership and labor market intervention is based on the scale of ownership rather than the real value of business capacity, the real value of the amount of social security premium expenditure and the real value of the ownership of venture capital in rupiahs.

\section{Research Main Findings}

Social protection has been effective in reducing poverty levels in East Java even in low levels. The condition is driven by Social Aid and IPTK programs are able to increase the basic capacity and business capacity of poor households leading to productivity increase. Low effectiveness level is believed due to low data accuracy of both target group coverage and target accuracy impacted to biased targets, wrong perception by poor households viewing as complicated adminis- tration, inaccurate timing of aid distribution, inappropriate period distribution with the needs.

Social security programs are not effective in increasing the income of poor households in East Java. It is in accordance with the nature of social security where it is merely trying to keep poor households from being poorer. Social security is only accepted by poor households if they are at risk of income vulnerability. The labor market intervention program is the most influential social protection program on increasing the income of poor households

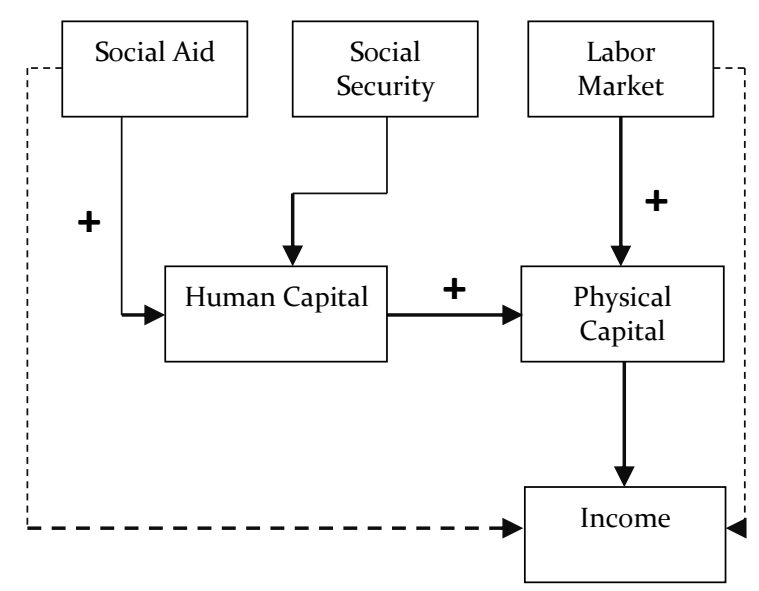

Figure 11 Impact of Social Safety Net Programs to Income

Figure 11 sums the impact of social safety net programs in Indonesia. Based on intervening equation of physical capital and human capital having significant positive relationship to income, social aid and labor market intervention have a positive and significant impact to income. However, even though social security has a positive relationship to income, the relationship is insignificant.

Social aid has a positive significant impact on human capital. Social aid, which aims to give access on basic education and health services, has a coefficient value of o.000097. This value implies that the 
implementation of social aid in Indonesia is inefficient in terms of its distribution. National Team of Accelerated Poverty Reduction ( $\mathrm{TNP}_{2} \mathrm{~K}, 2 \mathrm{2015}$ ) argues that social aid program in Indonesia still needs target refinement, integrated beneficiary database, and program sustainability. The beneficiary database is currently scattered. Beneficiary targets are also annually listed instead of continual process. Tobing \& Jonyanis (2014) adds that distribution pattern and administrative requirement are the main obstacles of efficient social aid distribution. Mardiana (2012) also argues that most poor households do not understand bureaucracy of the administrative process, so they do not meet the administrative requirements. Therefore, the main problem of social aid implementation is the inefficient distribution scheme and complicated administrative processes.

Labor market intervention has a positive significant impact on physical capital since labor market intervention programs are provided in the form of business capital grand for poor households. The capital grand provides both micro-scheme grand as well as low-interest banking credit. Labor market intervention is a program focusing on targeted groups which are productive poor households, having business or job. The coefficient of 0.225 shows that for each increment on labor market intervention scale raises physical capital by 0.225 scale. This number shows a relatively small impact. Thus, labor market intervention, which is applied through Business Credit (KUR), National Program for Community Empowerment (PNPM) or Co-operation. Putra (2015) stated that labor market intervention program needs an effective distribution, monitoring and evaluation mechanism to ensure the program sustainability. Wenagama (2017) also argued that the sustainability of labor market intervention program must be supported by active participation of the community. Therefore, based on those studies, the small coefficient of labor market intervention is caused by ineffective distribution mechanism, inefficient program implementation and lack of poor household participation.

Social security is the only social safety net program having positive but insignificant impact towards poor household income. Khafidoh (2015) showed that social security makes its holders feel comfortable while doing their job that positively impacts their income. However, Tobing \& Jonyanis (2014) revealed that not all poor households are social security holders. Many poor people do not have Indonesia Identification Card (KTP) which is the main administrative requirement of social security policy. Therefore, social security implementation needs some evaluation on its distribution and administrative process.

In summary, social aid has positive significant impact on human capital, human capital and labor market intervention have positive significant impact on physical capital, and physical capital has positive significant impact on poor household income. Based on coefficient values, labor market intervention is the program showing the highest impact on poor household income by increasing household's physical capital. Thus, all social safety net programs have a role in capital growth as the key to break vicious cycle of poverty. This finding is in line with Nurske in (Jhingan, 2014). The improvement of human capital and physical capital of poor households is very important step to poverty reduction. All social safety net programs which are social aid, social security and labor market intervention have 
a positive impact to reduce poverty. However, the empirical results show that the impact of physical capital on poor household income is still relatively small, that is 14,700 . This value is within $5 \%$ range of poverty line value of 305,000 . In other words, the current social safety net program can only help poor households which are slightly below the poverty line, but it cannot help poor households which are below $5 \%$ range of poverty line. Thus, the current implementation of social safety net programs still needs to be perfected.

Based on theoretical and empirical studies, this research indicates that the implementation of the national social protection program is in line with the theory of poverty reduction so that the existing program needs to be continued. However, given the small value of social protection effectiveness, it is advisable to evaluate the inclusion of poor households receiving social protection program, to simplify the distribution mechanism, monitoring and evaluation, to encourage participative role of the community to establish the program sustainability, to improve the capacity of officials administering social security program up to the lowest operational levels, to standardize the information system and provide trainings for information system utilization for the lowest operators, to develop this research with regard to its obstacles and constraints due to its measurement of business capacity conducted quantitatively caused by secondary data limitation.

\section{CONCLUSION}

Social safety net programs have been established by the government to reduce pressures on poor households, minimize social gap, provide a better life and accelerate effort to reduce poverty. A study on the effectiveness of social safety net programs becomes a necessity to evaluate the programs and suggest better activities and approach to be implemented in the future. Thus, this study analyses the impact and the effectiveness of social safety net programs to the income of poor households. This research focuses on East Java, a state the most contributing region to national poverty figure.

In finding the impact of social aid, social security and labor market intervention to poor household income, this study employs quantitative method namely equal simultaneous equation on secondary cross section data gathered through National SocioEconomic Survey (Susenas), March 2015.

The empirical results show that social aid and labor market intervention positively impact the income of poor households. Social aid programs, which increase the households' access to education and health services, escalate human capital of the households and increase their income. Labor market intervention, which provides cash grand in the form of business credit as well as guidance in the form of business training and assistance, is the most influential program to increase the income of poor households. Social security, on the other hand, has no significant implication towards poor household income. However, based on its nature, social security provides a safety net when a household faces unexpected situation such as labor redundancy, accident and death. Social security programs prevent poor households for being poorer.

This study suggests that current social safety net programs should be continued since these programs are very strategic and important in reducing poverty in Indonesia. 
However, target households of these programs have to be reevaluated. The distribution, monitoring and evaluation should be more effective and efficient. Another main problem of social safety net program implementation is the complicated administrative bureaucracy. Thus, integrated population database and administrative assistance are very important aspects to be established. Active participation is also required to maintain the sustainability of the programs. This study can be further expanded by adding qualitative analysis to compliment quantitative analysis that has been done.

\section{REFERENCE}

Asean Development Bank. (2003, July). Social Protection. Asean Development Bank, 107.

Asean Development Bank. (2016). Asean Development Bank Basic Statistics 2015. Manila. Retrieved from https://www.adb.org/sites/default/files/publicatio n/158591/basic-statistics-2015.xlsx

Central Bureau of Statistics (BPS). (2015). Data and Poverty Information in Districts and Municipals, 2015. (Subdirectorate of Social Vulnerability, Ed.). Jakarta.

Chen, M., Palmer, A. J., \& Si, L. (2016). Assessing Equity in Benefit Distribution of Government Health Subsidy in 2012 across East China: Benefit Incidence Analysis. International Journal for Equity in Health, 15. https://doi.org/10.1186/ s12939-016-0306-z

Cabinet Secretary (2016). Table of Government Spending Budget Based of Functionality 20122016. http://setkab.go.id/wp-content/uploads/ 2016/o8/Fungsi-Anggaran.jpg. Last accessed: 15 April 2018.

Director of Co-operation and UMKM State Ministry of Development Planning (Direktur Koperasi dan UMKM Bappenas) (2014). Report of UKKM Competitiveness. Bappenas. Jakarta

Djojohadikusumo, S. (1994). Thinking Development: Basic Economy Theory and Development economy. $\mathrm{LP}_{3} \mathrm{ES}$, Jakarta

Gujarati, D. N., \& Porter, D. C. (2012). Basic Econometrics (D. A. Halim, Ed.) (5 ${ }^{\text {th }}$ ed.). Jakarta: Mc Graw Hill.
Jhingan, M. L. (2014). Economic Development and Plannin. (D. Guritno, $16^{\text {th }}$ edition). Jakarta.

Kertonegoro, S. (1982). Social Security Principle and Application in Indonesia. Sentanoe Kertonegoro. Jakarta: Mutiara.

Khafidoh, S. (2015). The Influences of Incentives and Social Security to Employees' Productivity on REA Kaltin Plantations Ltd. E-Journal of Business of Administration, 3(3), 587-599.

Mardiana. (2012). Phenomenon of Cash Transfer Recepients. Journal of Socio-Economic Development, II(5), 130-143.

Maskie, G., \& Alfitri, R. (2014). The Impacy Analysis of City Term Based Credit (PNPM Mandiri Perkotaan) towards Poor Household Income. Jurnal Ekonomi Dan Pembangunan Indonesia, 3.

Priadana, M. S. (2010). Analysis for Determining Success Factors and Impacts from Group of Joint Venture in West Java. Trikonomika, 9(2), 78-86.

Putra, I. G. P. (2015). Effectiveness and Impacts of Rural Independent PNPM to Improve Welfare and Job Opportunity for Target Households in Abiansemal, Bandung Regency, 1-133.

Ratna Sari, R. (2017). Supervision for Subsidied Rice (Raskin) in Samarinda Municipality. E-Jurnal Ilmu Pemerintahan, 5(4), 1626.

Suharto, E. (2009). Poverty and Social Security. Bandung: Alfabeta.

Sumarto, S., Suryahadi, A., \& Widyanti, W. (2004). Assessing the Impact of Indonesian Social Safety Net Programs on Household Welfare and Poverty Dynamics. SMERU.

Supeno, E. (2011). Social Safety Net Implementation Rice Market Operation (JPS-OPKB) for Poor Family. Fisip UNAIR, 3.

$\mathrm{TNP}_{2} \mathrm{~K}$ National Team of Accelerated Poverty Reduction. (2015). Short-Term Priority of National Team of Accelerated Poverty Reduction.

Tobing, F. N., \& Jonyanis. (2014). Study of Poor Households Responses to Health Security Program in Sail, Tenayan, Pekanbaru. Online Journal of College Students of Social and Political Science , $1(1), 1-15$.

Wenagama, I. W. (2017). Effectiveness and Impacts of National Community Empowerment Program for Rural Independent Community (PNPM) to the Income of Poor Households. E-Journal EO Unud, 6(9), 1658-1685.

Widarjono, A. (2013). Econometrics: Introduction and Application Completed with Eviews Guidance, $\left(4^{\text {th }}\right.$ edition). Yogyakarta: UPP STIM YKPN. 